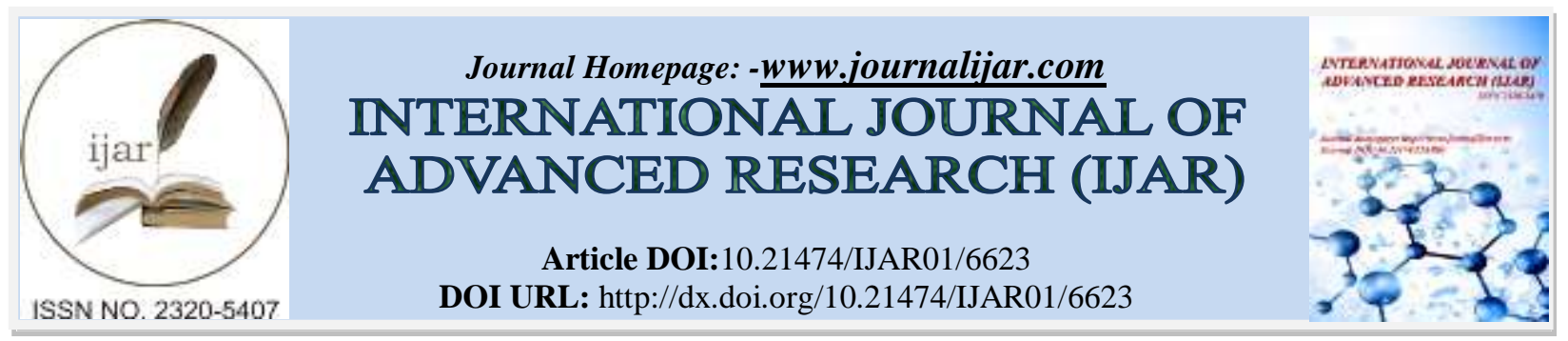

RESEARCH ARTICLE

\title{
COMPREHENSIVE SURGICAL CARE OF SEVERELY INJURED PATIENTS IN AYURVEDIC PROSPECTIVE.
}

\author{
Dr. Neelam Sajwan ${ }^{1}$, Dr. Danish Javed ${ }^{2}$ and Dr. Abha Singh ${ }^{3}$. \\ 1. Assistant professor, Shalya tantra, UAU, Main campus Harawala, Dehradun, \\ 2. Clinical registrar (Shalya), Ch. Brahm Prakash Ayurved Charak Sansthan, New Delhi, \\ 3. Assistant professor, Shalakya tantra, UAU, Main campus Harawala, Dehradun.
}

\section{Manuscript Info}

Manuscript History

Received: 24 December 2017

Final Accepted: 26 January 2018

Published: February 2018

Keywords:-

Orthopaedic, fracture, bhagna, Ayurveda.

\section{Abstract}

Acharya Sushruta, father of surgery, has described various surgical procedures viz. reconstructive, ophthalmic, dental, abdominal and orthopedic. He has classified six types of dislocations, twelve types of fractures, and classification of the bones, injuries, prognosis of fractures, principles of fracture management, viz., traction, manipulation, appositions and stabilization including some measures of rehabilitation and fitting of prosthetics and features of proper union. This study helps to explore the methods of identification, description of bhagna according to ancient time, management and simultaneously comparing it with the present day modern techniques and would certainly create interest as well as broaden the vision towards the Ayurveda.

Copy Right, IJAR, 2018,. All rights reserved.

\section{Introduction:-}

Trauma management has been practiced since Vedic periods. Ashwini kumars used to perform various surgeries like fixation of severed head, limb replacement, etc. The same science was developed, practiced and well documented by ancient sage. Acharya Sushruta has described the etiopathogenesis, classification, symptomatology, prognosis and management of various traumatic conditions i.e. soft tissue injuries, subluxation, dislocations and fractures in an elaborated way.

Orthopedic surgery is a broad and actively growing surgical specialty. It concerns the non-operative and operative treatment of disorders of the musculoskeletal system including bone, joints, muscle, tendons, ligaments, and nerves. The orthopedic surgeon must be familiar with the normal growth and development of the musculoskeletal system, as well as disorders that can arise from genetic or developmental abnormalities, trauma, infection, inflammatory process, the degenerative process, and neoplasm ${ }^{1}$.

\section{Aim and objectives:-}

1. To elaborate, evaluate, and discuss fracture management.

2. To rationalize the vision of Acharya Sushruta and the principles of health behind these regimens in the present time. 


\section{Material and methods:-}

All the references were collected from the various ancient ayurvedic literatures, research journals and websites related to the topic.

\section{Treatment of different types of fracture-dislocation:-}

Nail bed:-

When there is crushing of the nakhsandhi (nail bed) accompanied with accumulation of blood, it should be punctured with a thick needle; after the blood flows out, and the finger tip should be covered with moist flour or rice and bandaged ${ }^{2}$.

\section{Finger:-}

Finger which is fractured on its joints dislocated should be brought to its normal position, tied around with band of thin cloth and then bathed with ghee ${ }^{3}$.

Fracture is reduced by pulling the affected finger and the fractured phalanx becomes straight. Particularly in proximal phalanx a rolled bandage is placed in the palm and the affected finger is flexed over it and kept with a crepe bandage ${ }^{4}$.

\section{Sole:-}

Tala-bhagna (fracture of sole/ metatarsal bones) should be treated by anointing the foot with ghee; kusha (splint) is placed underneath and bandaged as stipulated. The patient is prohibited from doing any activity with the foot ${ }^{5}$.

Fractures of the base of the metatarsals usually are successfully managed by simple immobilization. Distal fractures of the metatarsal shaft, particularly the first metatarsal, are more often treated directly by internal fixation to ensure proper alignment of the weight bearing portion of these bones. Dislocations of the Lisflanc's joint can be associated with multiple fractures and can involve any number of the metatarsals ${ }^{6}$.

\section{Fracture of thigh and foreleg:-}

In case of fracture of bones of the foreleg (tibia and fibula) and thigh (femur), it is beneficial to adopt kapatashayana (lying in a specially made wooden box), the box having five keela/pegs to fasten the patient tightly, without allowing movement of the affected parts, two pegs on either side and one peg down below the heels. Even in case of fracture or dislocation of bones in pelvis, vertebral column, chest and clavicle the above method of treatment should be adopted ${ }^{7}$.

The gold standard of treatment of femoral shaft fractures is reamed, locked, ante grade intramedullary nailing performed through a closed technique ${ }^{8}$.

In majority of cases of tibia-fibula, closed treatment is advocated when the fracture is open or compound, in childern, when the fracture is stable and when there is no double tibial fracture. Open treatment through screws, intramedullary nails and plates is done on unstable fracture which cannot be reduced by closed method, in elderly patients, in whom early mobilization is required and in multiple fractures ${ }^{9}$.

Conservative treatment of fracture shaft of femur includes:

1. Fixed traction on a Thomas splint

2. Sliding traction on a Thomas splint

3. Sliding traction without splint

Operative treatment is usually performed by internal fixation with intramedullary (kuntscher) nail ${ }^{10}$.

\section{Fracture of arm:-}

Fracture of bones of the arm/ humerus should be treated in the same manner as the fracture of the thigh (pulled forward using a wheel and the leg bandaged ${ }^{11}$.

Reduction of the fracture shaft is unnecessary, as gravity corrects any overlapping or angulations. In the treatment one should take full advantage of gravity. This can be managed by U-slab method, hanging cast method, external splint and internal fixation ${ }^{12}$.

\section{Fracture of waist:-}

When a person is having kati-bhagna (fracture of waist hipbone, pelvic bone or lumbar vertebrae) it should be pulled either forward, upward or downward (as found necessary) and brought to its normal position and bandaged ${ }^{13}$. 
In case of posterior dislocation of the hip joint, the knee and hip are flexed gently to the right angle. At the same time the adduction and internal rotation deformities are corrected and finally thigh is pulled vertically upwards. The maneuver for reduction in anterior dislocation of hip is almost similar to that used for posterior dislocation. When the femur is lifted up, the thigh is gradually adducted and thus reduction can be performed. Under general anesthesia, central dislocation of the hip, the thigh is strongly pulled and the femoral head is levered outwards by adducting the thigh ${ }^{14}$.

\section{Fracture of ribs:-}

In parshukashthi bhagna the flanks should be anointed with ghee, the patient is made to sit, then nibandhani (controller-broad band of leather or thick strong cloth) tied around either from right or left side (to resist movement during respiration, coughing, laughing etc.), kavlika (soft pad made of inner fibers of barks or cotton threads-gauze and lint) is placed in between and then bandaged. The patient should then be made to lie either in a cauldron or bathing tub filled with oil ${ }^{15}$.

Fractured ribs are not important unless many are fractured, or unless there are serious injuries inside the patient's chest. If there are no complications, fractures of the ribs need no treatment except for pain. Lay the patient flat in bed for ten days, unless this interferes with breathing ${ }^{16}$.

\section{Dislocation of shoulder joint:-}

When the ansha-sandhi (shoulder joint) is dislocated, it should be lifted up from the axilla using a wooden rod and placed in its normal position and bandaged using swastika type of bandage ${ }^{17}$.

Under general anesthesia, with full relaxation, reduction should be done either by Kocher's method, Hippocratic method or gravitational traction. After reduction a gamgee or wool pad is placed in the axilla and a broad arm sling is applied in the position. A body bandage is applied over the arm of the affected side and the trunk in this position to prevent external rotation ${ }^{18}$.

\section{Dislocation of elbow joint:-}

It should be kneaded by fingers and placed in its normal; position, extension and flexion done, then warm oil poured over it in a stream. Similar treatment should be done in case of dislocation of knee, ankle and wrist joint ${ }^{19}$.

In elbow dislocation, reduction is performed by applying traction on the forearm with the elbow slightly flexed. Success is usually accompanied with a characteristic 'clunk' confirming reduction. Immobilization is done with a plaster back slab and a sling with the elbow ${ }^{20}$.

Fracture of metacarpals:-

When the bones of the hand are fractured both the palm should be made similar (by correcting the fracture); afterwards the area is bathed with raw oil and then bandaged ${ }^{21}$.

Spiral or transverse metacarpal fractures with minimal displacement require no reduction and simple crepe bandage may be used for comfort for a few days. Closed reduction is often followed by re-displacement, more and more surgeons prefer to internally fix such fractures after reduction with a kirschner wire through a dorsal incision across the fracture 22 .

\section{Dislocation of the clavicles:-}

When the akshkasthi (clavicles) are found dislocated, the area should be given fomentation and lifted up using a wooden pestle or pushed down if bulging up and then tight bandage applied ${ }^{23}$.

All acromio-clavicular joint separations can be treated non-operatively. The more active the patient and the more displaced the more likely the patient will benefit from an open reduction and internal fixation ${ }^{24}$.

\section{Dislocation of the lower jaw:-}

When the joints of the lower jaw is dislocated, the physician should anoint the area, give fomentation and place the lower jaw in its normal place by physical manipulation, then apply panchangi bandha (five tailed bandage); instilling drops of oil processed with vata mitigating and sweet drugs into the nose is greatly beneficial ${ }^{25}$. 
The mouth of a patient with a dislocated jaw remains permanently half open in an anterior open bite. Dislocations of the jaw are much easier to reduce if they are done earlier. Ask an assistant to stand behind the patient and hold his head. Now put some gauze over his lower posterior teeth on each side and press his premolar teeth downwards. At the same time press the underneath of his chin upward and backwards and bandage his jaw to keep his mouth shut for three days. Allow him to open it just a little for eating ${ }^{26}$.

\section{Shaky teeth:-}

When the teeth are found shaking but not fractured and if accompanied with bleeding and if the person is young, then teeth should be smeared with paste of drugs in cold condition, followed by sprinkling cold water externally and then applying paste of sandhaniya drugs. The patient is instructed to drink milk through hollow reed of lily flower. When this condition is found in an old person the shaky teeth should be pulled out and discarded ${ }^{27}$.

Although injured teeth do not threaten life, they are actually painful, especially when the pulp is hanging out. If the crown of a patient's tooth is missing, its exposed pulp will be visible as a pink spot on the root surface. If a tooth is only mildly subluxed, leave it in place, it will probably tighten up and live. If a tooth is so loose that it can lift up and down in its socket, remove or replant it. If there is an opening between a patient's antrum and his mouth, try to close it. If the antrum is already infected, leave it open and irrigate it daily. Take a chest x-ray, in case the patient has inhaled the missing dentures ${ }^{28}$.

\section{Fracture of nose:-}

When the nose is found sunk inside or distorted, it should be made straight with the help of an iron rod, hollow tubes having opening at both ends are introduced into the each nostrils anointed with ghee, bandaged and then bathed with ghee $^{29}$.

Closed reduction of nasal fractures may be performed under local or general anesthesia. Unfortunately, many, if not most, show some deformity upon final healing, requiring rhinoplasty if airway obstruction is present or if improved appearance is desired ${ }^{30}$. When a patient's injured nose is displaced, swollen and bleeding its severe bleeding is controlled by packing the nose. Walsham's forceps is used to reduce the patient's nasal bone and Ash's forceps to straighten his nasal septum. Instead of these forceps, any stout clamp can be used. If the fracture is mild, no splint is needed. If the fracture is severe, splint it, either with a plaster cast, or with lead splint ${ }^{31}$.

\section{Fracture of ear:-}

When the ear pinna is found fractured it should be placed in its normal position, bathed with ghee, bandaged with cloth soaked in ghee; after that it is treated like a fresh wound ${ }^{32}$.

Reconstructive approach of the ear is often determined by size and location of the defect. When helical defects are too large for this solution, local flaps may be used to close or re-create the missing tissue. Even larger defects of the upper and middle thirds of the ear may be reconstructed with large local skin flaps combined with contralateral cartilage grafts or contralateral composite grafts ${ }^{33}$.

\section{Fracture of skull bone:-}

When the flat bones of the skull are found fractured without brain matter coming out, then the area should be bathed with mixture of honey and ghee and bandaged; the patient instructed to drink medicated ghee only as food for seven days $^{34}$.

\section{Treatment of swollen body parts:-}

When any part of the body is swollen but not having a wound, due to either falling from height or assault (by weapons) the paste of drugs of cold potency should be applied cold or cold liquids poured over that part (for some time $)^{35}$.

\section{Treatment of fracture with wound:-}

When there is a wound at the site of fracture, the pieces of dry bone projecting out, should be cut and removed taking care not to create another wound nearby; afterwards treated as fracture with a wound ${ }^{36}$. After proper soft tissue management (excision, cleaning), fracture with wound is treated either as closed fracture or undreamed nailing, plate fixation or external fixation is done according to the grade of the fracture ${ }^{37}$. 


\section{Discussion:-}

Basically the fracture management is described under three headings: Reduction, Retention and Rehabilitation. Reduction i.e. to bring the fractured segments in proper alignment without any displacement was previously done by manually i.e. aachan (pulling forward/extending), peedan (pressing down) and sanchepa (flexing). These are physical manipulations to be done by the physician himself; these require good knowledge of structure and functions of bones and joints as well as experience, skill and intelligence on the part of the physician. During these manipulations, the patient experiences severe pain. In ancient days strong attendants held the patient tight during these acts for want of good anesthesia.

Nowadays reduction is not only performed manually but also done by gravity traction, skin traction (in fracture femur of hip), skeletal traction a kirschner, Steinmann pin or Denham pin are also used.

During the ancient time for fracture immobilization or retention, the bark of madhuka (Madhuca indica), udumbar (Ficus glomerulata), asvattha (Ficus religiosa), palasa (Ficus lacor), kakubha, vansa (Bambusa arundinacea), sarja (Vateria indica) and vata (Ficus bengalensis) were used as kusha/ splint. It has been replaced now as plaster cast and fiber glass for the fracture immobilization.

The importance of physiotherapy or rehabilitation (restoration of the normal function of the fractured bone) was also appreciated by Acharya Sushruta. In tala-bhagna (fracture metacarpals), the patient is instructed to hold a ball of mud in his hand first for some days, then a ball of salt and later a stone to gain the power gradually. Holding the stone should be continued for some days, even after the strength of the palm is regained.

Acharya advocates the dietary regimen to the patients also. Fractured patient should not indulge in foods which are salty, pungent, alkaline and sour; in copulation, sunlight, and physical exercise and dry foods. Sali rice, meat soup, milk, ghee, soup of lentil, food and drinks which are stoutening should be given to the patients of fractures. Guarniero R et al. (1992) assessed the effect of nutrition on fracture healing in controlled animal model; the results showed protein nutrition support on the healing of long bone fractures. Chen et al. (2009) showed that for a smalland medium-sized fractured gap, the nutrient supply is sufficient for bone healing; and for a large-sized fractured gap, non-union may be induced either by deficient nutrition supply or by inadequate mechanical condition.

Fracture of shaft of long bones if found irregular/ uneven or bulged up due to malunion even after healing, it should be broken again, ends of the bones placed properly and then treated like a fresh fracture ${ }^{38}$. The same principle is followed in modern orthopedic surgery. Once diagnosed and located, surgery is the most common treatment for a malunion. The surgery consists for the surgeon re-breaking the bone and realigning it to the anatomically correct $\operatorname{position}^{39}$.

Apart from the general measurement Acharya also gives emphasis on the supplementary treatment viz. for fracture of upper portion of the body, therapies such as mastikya (a variety of sirobasti) and karna poorana (filling the ear) are beneficial; for fractures of bone of extremities, drinking of medicated ghee, nasal drops and oil enema are useful. Physician should try to prevent suppuration of fractures; if suppuration of muscles, veins and ligaments take place, it (fracture) become difficult to cure ${ }^{40}$.

Decoction of nyagodhra etc. should be used cold for pouring on the area of the fracture. If pain is present, milk boiled with pnachmula is used for bathing. Lukewarm chakra tail is also used for bathing. Bathing with liquids and applying pastes of drugs should be appropriate to the doshas. Since majority of drugs has shown tikta, madhur, kashaya rasas as predominant and most of the drugs bearing laghu, ruksha guna. Katu vipaka, ushna veerya, madhur rasa mitigate the vitiated doshas and consequently the asthi dhatu.

\section{Conclusion:-}

Acharya Sushruta has described orthopedic chapter with details of all the musculoskeletal injuries and related management which are even appreciated in modern science and the orthopedic principles set by Acharya have withstood with the test of time. All the operative procedures are appreciated by the present day modern surgeons involve the refined, modernized form of these techniques. By analyzing the fracture-dislocation management, as recorded in the Sushruta Samahita, we can say that the fundamental steps are similar to the steps that are followed in modern orthopedic surgery. The main difference is that all the procedures, related instruments (i.e. external splint 
and internal fixation, screws, wire, anesthesia, diagnostic tools viz. x-rays, MRI etc. have been evolved in a refined, sophisticated and advanced form. In that time fracture-dislocations were diagnosed in the basis of signs and symptoms only, but nowadays various diagnostic tools are there for accurate diagnosis. Acharya Sushruta has evolved extremely useful, logical and practical approach of determining various types of fractures along with symptoms, prognosis, healing time of fracture according to different age groups and management. The orthopedic principles described by ancient Acharyas in various ayurvedic scriptures are so relevant with a very sound base that they holds good even in present time.

\section{References:-}

1. Schwartz's Principles of Surgery, Ninth edition, F. Charles Brunicardi, chapter 43, Orthopedic Surgery, Mc Graw Hill Medical, 2010.

2. Kawiraj Ambikadutta Shastri, 2006, Sushruta samhita, Chikitsa sthana, 3/23, Chaukhamba Sanskrit Sansthan, Varanasi.

3. Ibid $3 / 24$

4. S. Das, 2005, A Concise Textbook of Surgery, Chapter 23, p-359, published by Dr. S. Das, 13, Old Mayors' Court, Kolkata.

5. Prof. K.R.Srikantha Murthy, 2016, Susruta samhita, Chikitsa sthana, 3/25, edited by Prof. K.R.Srikantha Murthy, Chaukhamba orientalia, Varanasi.

6. Schwartz's Principles of Surgery, Ninth edition, F. Charles Brunicardi, chapter 43, Orthopedic Surgery, Mc Graw Hill Medical, 2010.

7. Kawiraj Ambikadutta Shastri, 2006, Sushruta samhita, Chikitsa sthana, 3/48-49

8. Schwartz's manual of Surgery, F. Charles Brunicardi, chapter 42, p-1148.

9. S. Das, 2005, A Concise Textbook of Surgery, Chapter 24, p-384, published by Dr. S. Das, 13, Old Mayors' Court, Kolkata.

10. Ibid, 24, p-375.

11. Achrya Priyavat Sharma, 2009, Shri Dalhanachrya virachit nibandhsangrha, Sushruta samhita, Chikitsa sthana, 3/36, Chaukhamba orientalia, Varanasi.

12. A Concise Text Book of Surgery, S. Das, 2005, chapter 23, p-337, published by Dr. S. Das, Old Mayors' Court, Kolkata.

13. Prof. K.R.Srikantha Murthy, 2016, Susruta samhita, Chikitsa sthana, 3/28, edited by Prof. K.R.Srikantha Murthy, Chaukhamba orientalia, Varanasi.

14. S. Das, 2005, A Concise Textbook of Surgery, Chapter 24, p-363, published by Dr. S. Das, 13, Old Mayors' Court, Kolkata.

15. Prof. K.R.Srikantha Murthy, 2016, Susruta samhita, Chikitsa sthana, 3/29-30, edited by Prof. K.R.Srikantha Murthy, Chaukhamba orientalia, Varanasi.

16. Primary Surgery, vol-2, Trauma, Chapter 65, Thoracic injuries, Maurice King and Peter Bewes, Oxford medical publication, 2005

17. Kawiraj Ambikadutta Shastri, 2006, Sushruta samhita, Chikitsa sthana, 3/ 31-33, Chaukhamba Sanskrit Sansthan, Varanasi.

18. S. Das, 2005, A Concise Textbook of Surgery, Chapter 23, p-331, published by Dr. S. Das, 13, Old Mayors' Court, Kolkata.

19. Kawiraj Ambikadutta Shastri, 2006, Sushruta samhita, Chikitsa sthana, 3/ 32-33, Chaukhamba Sanskrit Sansthan, Varanasi.

20. S. Das, 2005, A Concise Textbook of Surgery, Chapter 23, p-346, published by Dr. S. Das, 13, Old Mayors' Court, Kolkata.

21. Prof. K.R.Srikantha Murthy, 2016, Susruta samhita, Chikitsa sthana, 3/34-35, edited by Prof. K.R.Srikantha Murthy, Chaukhamba orientalia, Varanasi.

22. S. Das, 2005, A Concise Textbook of Surgery, Chapter 23, p-358, published by Dr. S. Das, 13, Old Mayors' Court, Kolkata.

23. Prof. K.R.Srikantha Murthy, 2016, Susruta samhita, Chikitsa sthana, 3/36, edited by Prof. K.R.Srikantha Murthy, Chaukhamba orientalia, Varanasi.

24. Schwartz's manual of Surgery, F. Charles Brunicardi, chapter 42, p-1152.

25. Kawiraj Ambikadutta Shastri, 2006, Sushruta samhita, Chikitsa sthana, 3/ 30-40, Chaukhamba Sanskrit Sansthan, Varanasi. 
26. Primary Surgery, vol-2, Trauma, Chapter 62, Maxillofacial injuries, Maurice King and Peter Bewes, Oxford medical publication, 2005

27. Achrya Priyavat Sharma, 2009, Shri Dalhanachrya virachit nibandhsangrha, Sushruta samhita, Chikitsa sthana, 3/41-42, Chaukhamba orientalia, Varanasi.

28. Primary Surgery, vol-2, Trauma, Chapter 62, Maxillofacial injuries, Maurice King and Peter Bewes, Oxford medical publication, 2005

29. Achrya Priyavat Sharma, 2009, Shri Dalhanachrya virachit nibandhsangrha, Sushruta samhita, Chikitsa sthana, 3/43-44, Chaukhamba orientalia, Varanasi.

30. Schwartz's Principles of Surgery, Ninth edition, F. Charles Brunicardi, chapter 45, Plastic and Reconstructive Surgery, Mc Graw Hill Medical, 2010.

31. Primary Surgery, vol-2, Trauma, Chapter 62, Maxillofacial injuries, Maurice King and Peter Bewes, Oxford medical publication, 2005.

32. Kawiraj Ambikadutta Shastri, 2006, Sushruta samhita, Chikitsa sthana, 3/ 45, Chaukhamba Sanskrit Sansthan, Varanasi.

33. Schwartz's manual of Surgery, F. Charles Brunicardi, Ninth edition, chapter 45, Plastic and Reconstructive Surgery, Mc Graw Hill Medical, 2010.

34. Prof. K.R.Srikantha Murthy, 2016, Susruta samhita, Chikitsa sthana, 3/46, edited by Prof. K.R.Srikantha Murthy, Chaukhamba orientalia, Varanasi.

35. Ibid $3 / 47$

36. Ibid $3 / 53$.

37. Treatment of open fractures, Department of traumatology and Hand Surgery, University of PECS, Dr. Laszlo G Not.

38. Kawiraj Ambikadutta Shastri, 2006, Sushruta samhita, Chikitsa sthana, 3/52, Chaukhamba Sanskrit Sansthan, Varanasi.

39. "Malunion". llila.com, Limb Lengthening Institute of los Angeles, Retrieved 20 March 2015.

40. Achrya Priyavat Sharma, 2009, Shri Dalhanachrya virachit nibandhsangrha, Sushruta samhita, Chikitsa sthana, 3/54, Chaukhamba orientalia, Varanasi. 